解 説

\title{
微生物の産業における新しい利用法
}

\section{井上 真由美*}

\section{1. 微生物の能力と個性}

フランスの一流のレストランにはブドウ酒が 1,000 種, チーズぶ300種ぐらいいつでもそろつているという。拉 いしいものが好きなフランス人の習慣もわれわれにとっ ては，こんなに多くの種類がとおどろくばかりである。 ブドト酒はブドウの果汁にブドウ酒酵母.(Saccharomyces ellipseudeus) の純粋培養した液を加えて10〜 $15^{\circ} \mathrm{C} に 3 〜 4$ 週 間発酵させると, 果汁のなかのブドウ糖がアルコールと 炭酸ガスとに変化し，ブドト酒ができる。化学の本には その反応ゔつぎの式で示されている。

$$
\mathrm{C}_{6} \mathrm{H}_{12} \mathrm{O}_{6} \longrightarrow 2 \mathrm{C}_{2} \mathrm{H}_{5} \mathrm{OH}+2 \mathrm{CO}_{2}
$$

ブドウ酒のうま味や微妙な風味の化学:成分は，この化 学式で示されるような簡単なものではない。ブドウの果 汁からブドウ酒酵母の作用でできるアルコール以外の微 量の芳香性物質の種類とその美しい調和が，ブドウ酒の 価値を決定する重要な役割をはたしているといえる1)。 それらの戍分はメチルアルコール， $n$-プロピルアルコー ル，イソアミルアルコール，高級アルコール（グリセリ ンなど)，アセトアルデヒド，2-3-ブチレングリコール， 揮発酸, エステル, リンゴ酸, コハク酸などの有機酸と 多種におよび2)，それらの成分引゙きわめて安定した美し い調和の比率で作りだされている点がブドウ酒酵母の独 特な能力, 個性ともいえる特性だと篗者は考えている ${ }^{2)}$ 。 酵昷の生きた力で各種つ物質を合成する作用を微生物の 能力, 微妙な美しい調和を作りだす機能を微生物の個性 というように感じられる。

チーズはわ泪でもその需要ゔふえて広く普及するよ うになつたチーズといえば栄養価のすぐれた食品とい らイメージがわが国では強い。欧米ではチーズは 800 種 も作られ，すべてし好品として愛用されている。したが つてわが国のものとちがつて香気がつよく，するどい昧 のするものゔ多く，な机なと食欲が抗こらないほどで

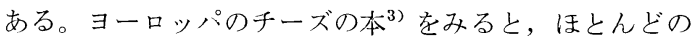
製品ぶアオカビ (Penicillium camemberti, P. roqueforttii な ど）の作用で熟成させて作つたもので，チーズの切口に
はみどりやブルーのしま模様がみられ（写真 1)，われわ れの日常親しんでいるチーズとはかなり異なつた感じを 受ける。チーズの熟成に利用されているアオカビは人体 に有害でなく，チーズのやわらかい風味と特徴を作りだ すのに重要な役目をはたしている。

わが国の気候風土はその環境がカビや細菌の発育によ く適合しているため，らまい清酒やみそを作る技術が古 くから発達し，食生活を豊かにする点では成功している といえよう。多くの食物のなかで味のすぐれたもの, 香 りや風味のよいものはすべて微生物の作用を合理的に応 用したものであることに気方つくであろう。

このような味, 香気, 風味の化学成分は現代の化学分 析の技術では繶単に测定できるが，逆にこれらの微妙な 成分をととのつた調和をもつように混合してウイスキー や清酒とまつたく同じものを作ろうとしても今日の化学 の力では不可能である。これを作りうる微生物には学ぶ ところが多い。

微生物の性質と作用は, 微生物の種類によつて千差万 別といえるばかりでなく, 微生物の働きはまことに偉大 な力を発揮することが具体的な新しい応用例を創造する 例からも証明される。この事実はわれわれに限りない大 きな夢と研究開発の勇気を与えるように感じられる4 。

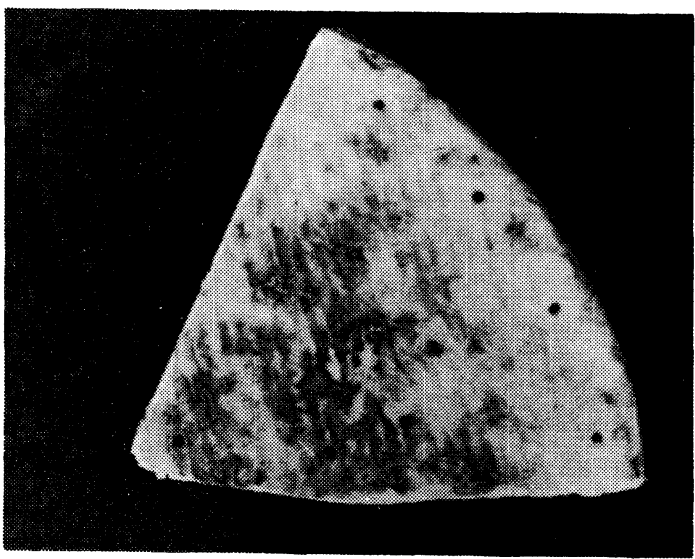

写真 1 アオカビによつて熟成されたチーズ

\footnotetext{
* 井上微生物災害研究所
} 
わが国で伝統的に製造されている酒，しょう油，みそ などの醸造によつて作られる古典的な製品でさえも，現 在年䦥 2 兆円を越える生産をあげているのであるから， 他の産業に比べて微生物の偉大な力には注目せざるをえ ない。さらにこの20年汭かりの間にこれらの古典的な微 生物の利用技術はめざょしく進展し, 近代的な微生物応 用の産業といえる形にまで成毬しだ”。

\section{2. 微生物産業の時代}

抗生物質の発見とその実用化への研究開発が近代応用 微生物学のめざましい発展への大きな原動力となつたと 考えられる。ペニシリンが 1929 年に Fleming によつて 発見されてから，医薬品として実用化されるまでには多 くの科学者の協力と,長い時間と,多額の費用を要した。 当時のアメリカにおいてさえ, 抗生物質の研究開発には いままで経験したことのないような大きな困難に遭遇し たといわれる。実際には細菌学, 発酵学, 生理学, 薬学, 有機化学，医学などの幅広い専門分野の研究者の技術的 な協力と，さらに機械工学的な応用によってはじめて実 用化の成果をあげることができた。これらの努力は，そ の後の微生物の研究の発展に, 新しい大きな影響力をお よぼす結果となっている。あらたに実用化された抗生物 質は約40種にもの淮り，現在ではガンに有効な治療薬が 微生物によって作りだされようとしている。微生物が自 己の細胞つ生きた力で合成する各種の有用な有機化合物 は，現在の有機合成化学の技術ではとうてい合成できな 、複雑な構造式をもつものばかりである。しかし抗生物 質の研究が進歩寸ることによつて有機化学の新しい局面 がひらかれ，その推進力は大きな力になっていることは 注目すべき事実といえよう。このように微生物はわ机わ れが想像したこともない未知の複雑な構造をもつ有用な 物質を簡単に合成する能力をもつていることが応用微生 物学の発展からしだいに明らかになつてきた。

さらにこれらの新しい技術が基礎になつて,アミノ酸, タンパク質, 農薬が微生物工学的に大量生産されるよう になり，21世紀はまさに微生物産業の時代になるとさえ いわれている。その応用も新しい化合物の合成のなか で, 将来増加する人口をまかなうための食糧資源として の素材の製造，その加工に用いられる味，香り，風味な どの材料の微生物による合成, 口のなかでも舌の上など で感じる食物としての独特な感覚を与える物質の合成な どその範囲はきわめて広いものがある。現在においても 微生物の各方面への利用はまだその入口にようやく到着 したばかりのように感じられ，本格的な研究開発と応用 は今後に期待されるところが大きい。

\section{3. 多様化する微生物の利用法}

1972年3月20日から25日まで，京都で世界47力国，約 1, 100 名の専門家が参加して第 4 回国際発酵シンポジウ ム5)がひらかれた。多くの研究発表からみて，微生物を 培養してえられる各種の酵素が，新しい多方面での用途 が期待されるものと考えられる。とくに最新の発酵」学 はわわ国の古くからの伝統的な技術を大きく前進変ぼう させながら新しい面を推進させている点う現在の特徴の ようにみえる。このシンポジウムで, 従来の研究の延長 として考えられる新規の抗生物質や酵素を糖を含む天然 物の材料からではなく，石油をあらたな資源として用い た発酵法によって生産する技術の報告が多くみられた。 また現在環境の污染によつて大きな社会問題となつてい る産業廃㶳物処理にも微生物の能力をかりようとする新 しい方向の研究が真剣に進められる傾局がみられたこと は注目に価することである。

P. H. Hsich によると下水処理場から分離した細菌を 混合して連続培養することによって，農楽のパラチオン を含む廃液や河川の水を処理して有害な化合物を分解消 失させるこ上に成功している6)。またわが国で開発され た研究によれば, Pseudomonas 菌の生産する酵索液を用い て，有機水銀化合物を含む廃水に処理させ，完全に有機 水銀を分解させるなどの独創的な成果があがりつつあ $る^{7)}$ 。

また鉣山におけるバクテリアリーチングの技術につい ての研究も発表され，鉱床内に細菌を増殖させ，低品位。 鉣からも有用な金属を回收することができ，岡山県の人 形峠のウラン鉣からウラニウムの回収が実験的に成果を あげつつあるといわれる8)。

微生物の生産する酵素の新しい利用法として，最近不 溶性酵素というものが着目され ${ }^{9)}$ ，元来は水にとける醳 素を不溶性の物質に吸着固定させたり，酵素の外側に不 溶性の半透膜を包みこむなどの方法で定着させることに より，イオン交換樹脂のように固体の触媒として連続的 に利用しようというもので，L－アミ／酸を精製すると きにこれを灾用すると $40 \%$ もストが低くなり，さらに 将来性引゙あるといわれる。

自然界には非常に変つた能力をもつ酵母や細菌か 存在 している。石油の成分を炭素源として栄養分に利用し， 硫安や尿素のような安仰な窒素化合物の添加によつて高 純度のタンパク質を合成する酵母の研究が進み，現在で は石油からタンパク質を微生物「学的に大量生産するこ とが害用化に達している。

体重 $500 \mathrm{~kg}$ の牛 1 頭呅 1 日に生産する肉の量は $0.4 \mathrm{~kg}$ にすぎない。その生産速度はおそく，同時に牛は食糧に なりうる材料在飼料として食べるので全体からみると能 
率がわるい。微生物は季節に関係なく，もっと短時間に 連続的に增殖し， $500 \mathrm{~kg}$ の酵母は24時間で10トンの菌体 に增殖する ${ }^{10}$ 。

グルタミン酸ソーダも現在では大豆や小麦を原料に使 わず,石油から容易に作りだされる酢酸を主原料に用い， 硫安を添加して Corynebacterium glutamicum という細菌の 培養によ一て収率よく製造されるように変つてきた。そ ればかりでなく，人体の栄養にとつて重要なアミノ酸で ある，リジン，スレオニンなどか微生物の力で工業的に

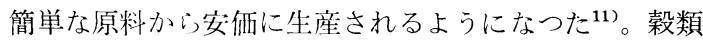
に微生物】学的に作られたアミノ酸を添加すれば, 動物 性のタンパク質に匹敵する栄養価の向上が期待できる。

その後の研究から，変つた性質をもつ微生物がつぎつ ぎと発見された。メタンを炭素源に利用するPseudomonas methanica はメタンのほかにメタノールだけを唯一の炭素 源として生展することができる菌である。Pseudomonas methanitrificans はメタンのみを岑素源とし，空気中の窒 素を利用して生育で导る独特な能力と個性をもつ細菌で ある。その他にメタンの代りにブタン, テトラデカン, トルエンなどをそれぞれ炭素源に利用する窒素固定菌も 知られ，このような細菌を適当な炭化水素とともに土中 に加えておくと空気中の窒素が固定され，肥料の節約に なる ${ }^{12)}$ 。

現在 nーパラフィンを原料に用い，これから140\%の高 収率で，徵生物の菌体を生産する技術が実用化されてい る。また石油から容易に作られるメタノール，エタノ一 ルを原料として，微生物の作用で食べられるタンパク質 を製造する研究も行なわれている。

わろ゙国の大企業が石油タンパク質の製造研究と商品化 を進めている。軽油, 灯油に含まれているn-パラフィン を，炭化水素を資化する能力のある酵母に利用させ，そ の菌体からタンパク翼を抽出製造するもので，当面は家 畜や養魚の飼料として企業化するが，将来は牛肉に劣ら ない味をもつ人工肉を作ることが可能といわれている。 1939年. 8 月厚生省から人体にたいする安全性, とくに発 ガン性について疑問がだされた。その後通産省, 農林省, 科学技術庁が検討した結果，1970年になつて最終製品中 の発ガン物質 (3,4-benzpyrene) は許容限度をはるかに 下回っていることが明らかになり，正式に商品として認 可される見通しがついた ${ }^{13)}$ 。現在でも魚粉，大豆かすな ど，飼料に混合するタンパク資源は，90\%を輸入にたよ つている。10年後には 300 万トンを輸入しなければなら ない状態にあるので，石油タンパク質の真価は十分に発 揮されるようになろう。すでにニワトリ，牛などの家畜 からハマチ，ウナギなどの養魚への実用化試験では魚粉 とまつたく变わらないよい成績がえられている ${ }^{14)}$ 。

n一パラフィンを原料として酵母を培養する場合は，培
養が終了したときも培地のなかに油が残存し，そのため 菌体が油で污れ, 処理に大きな労力を要するのが久点と されている。油のなかには 3-4 benzpyrene が存在する。 石油を原料に用いないでガス状の炭化水素, たとえばメ タンを使ってメタンを資化する細菌を培養增殖させ，同 じ方式でタンパク質を製造する技術が考案された。n-パ ラフィンは 1 キロ当たり30円で, 石油の埋蔵量は 700億 トンといわれるのにたいし，天然颃はは地下に 100 兆 $\mathrm{m}^{3}\left(1 \mathrm{~m}^{3}=0.73 \mathrm{~kg}\right)$ も貯えられ，1 キロ当たりの価格も 7 ～ 8 円ときわめて安いので，ガス状の炭化水素を原料 に用いる製造法は将来性が高い。また培養後の菌体も水 洗するだけで十分にきれいになるという利点をもつてい る。この製造法に用いられる徴生物としては Bacillus methanica や Pseudomonas methanica があげられるが，酵母 に比べて菌体内のタンパク質の含有量が多く, とくにメ チオニンを多量に含む点が栄養学的に優れている。この 技術はさらに進み, 将来は石油タンパク質に代る製品と して重要なものになろう ${ }^{15)}$ 。その後工業技術院がメタノ 一ルを原料として微生物によるタンパク質研究開発にと りかかつたが，メタノールは安く，水にとけるので精製 の操作が容易で収量う向上する。この製品も新しい食品 の素材や飼料になりうるものである ${ }^{16)}$ 。

さらに微生物を用いて新しいタンパク質製造の技術が 確立されようとしている。微生物工業技術研究所で, 秋 田県の油田地帯の土壤から分離したバクテリアを用い て，無機塩を含む培地中に炭酸ガス $2 \%$, 酸素 $3 \%$ ，窒

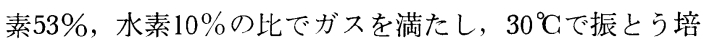
養を行なつた結果, 6 日後には菌体が約 400 倍に増殖し, タンパク質の含有量は $42.6 \%$ を示したといわれる。この 方法は原糊に石油や天然ガスのような有機化合物を使わ ない画期的な技術である ${ }^{17}$ 。

現在の技術では多種のアミノ酸, イノシン酸, グアニ ル酸など味の化学成分がすべて微生物の力で工業的に作 りだされる時代になつた。これらは天然物に近い味をも つているのでその組み合わせによつて，たとえばタイ， エビ，ウ二，チーズ，トリなどの味を合成することがで きる。チーズの熟成に用いられるアオカビを大量に培養 して, 芳香成分が合成される ${ }^{18}$ などの例から将来は食品 の本体となる舌ざわりや，歯ごたえを作る化学的物質， 食物の形を作る物質が微生物によって作りだされる可能 性がでてきた。これらの原料はすべて石油, 天然ガス， 無機物というような夢が実現する日も近いと思われる。

以上述べたように, 微生物の能力と個性の開発利用は われわれの日常生活に関係の樑、食品, 医薬品, 香料, 衣料などから鉣石のなかの有用金属の溶出精製，水中微 生物, 土壤微生物による農薬や有害物資の分解, 無毒化 などの公害防止にまで，広範囲に応用される時代になつ 
た。これらの微生物の応用は，まだやっとその緒につい た感じであつて, 本格的な研究は今後に大きな夢が期待 される。

\section{4. 微生物の種類とその性質}

微生物 (microorganism) とはバクテリアや酵母のよう にきわめて微小な生物で，肉眼ではその細胞の形をみる ことができない。影微鏡によつてはじめてその形態を観 察することが可能となる。微生物の種類は多く，その形 態も種類によつて異なるぶ，微生物のもつ実際的な働き についてはかなり古くから知られ，それを利用してき た。腐敗, 発酵, 醸造などの現象として長い間にわたっ て，人類の生活に密接な関倸をもち続けてきた。これら の現象が微生物の生きた作用によつて, 生物体内の化学 反応として進行することは今から約 100年前に Pastcur によつてようやく解明されるに至つた ${ }^{19)}$ 。

微生物は有機物, 無機物, 水から構成され, 各成分の 1 部は炭水化物, タンパク質, アミノ酸, 核酸などの形 で，また 1 部は無機塩や有機酸の形で微生物に栄養源と して利用される。この点は人間の栄養と根本的にはよく 似ているぶ, 微生物は非常に微量の栄養分で十分に生育 することができる。炭素源としてデンプン，ブドウ糖を エネルギ源に利用寸るが，菌の種類によつては酢酸やク エン酸などの有機酸, アルコール, 石油, 天然ガスなど の成分をも完全に利用する能力をもつている。窒素源と してはタンパク質，アミノ酸のほかにアンモニア化合 物，硝酸塩を利用して微生物の体に同化できる菌が多く 自然界に存在する。カルシウム，マグネシウム，カリウ ム, リン, マンガン, 鉄の徵量の存在が微生物の発育に は必要である。

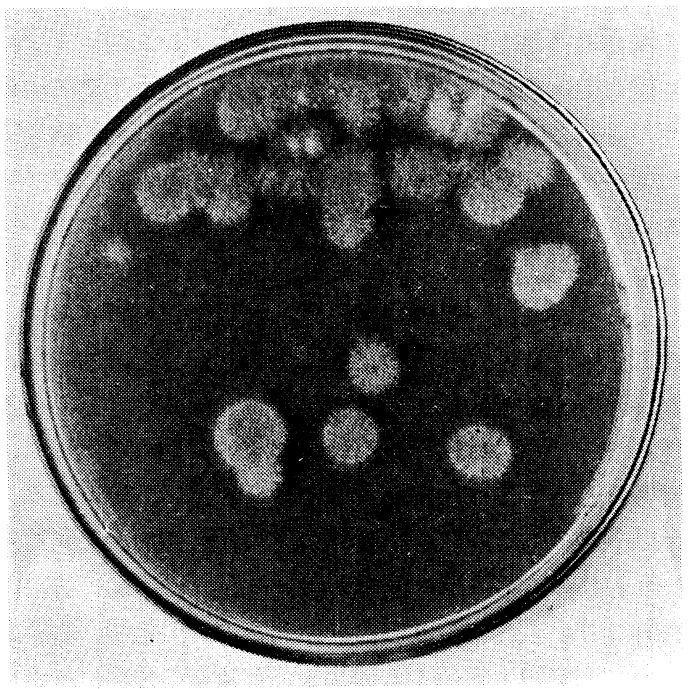

写真 2 カビのコロニー
これらの微生物の発育に必要な成分を混合して水にと かしたものを培地といい, 微生物の種類で多少その混合 割合を変えなけ机ばならないため, 微生物を培養するた めに考案された培地の種類はきわめて多い。代表的なも のとして多くのカビと酵母の培養に適した培地に potato dextrose agar と細菌の倍養に適した肉汁培地がある。 その組成を示す。

(1) potato dextrose agar

$\begin{array}{lc}\text { バレイショ } & 200 \mathrm{gr} \text { の抽出液 } \\ \text { ブドウ糖 } & 20 \mathrm{~g} \\ \text { カンテン } & 30 \mathrm{~g} \\ \text { 純 } \quad \text { 水 } & 1,000 \mathrm{~m} !\end{array}$

(2) 肉汁培地

$\begin{array}{lc}\text { 肉エキス } & 3 \mathrm{~g} \\ \text { ペプトン } & 5 \mathrm{~g} \\ \mathrm{NaCl} & 5 \mathrm{~g} \\ \text { カンテン } & 30 \mathrm{~g} \\ \text { 純 水 } & 1,000 \mathrm{~m} l\end{array}$

培地はフラスコ内で調製し, 綿栓を施してオートクレ ーブ内で $120^{\circ} \mathrm{C}, 15$ 分間加熱して培地中の雑菌を完全に 殺菌したのち, あらかじめ殺菌して扔いた径 $9 \mathrm{~cm}$ のシ ヤーレに約 $30 \mathrm{ml}$ ずつ分注して固化させて平板培地を作 る。白金線の先端に試料 (水, 土壤, 食品工業材料な ぞ）を少量つけて，平板培地の表面に塗沫し， $30^{\circ} \mathrm{C} に 2$ 〜 3 日保つと, 平板上に分散された微生物於自由に分裂 して増殖し, 写真 2 と写真 3 に示したようなコロニーを

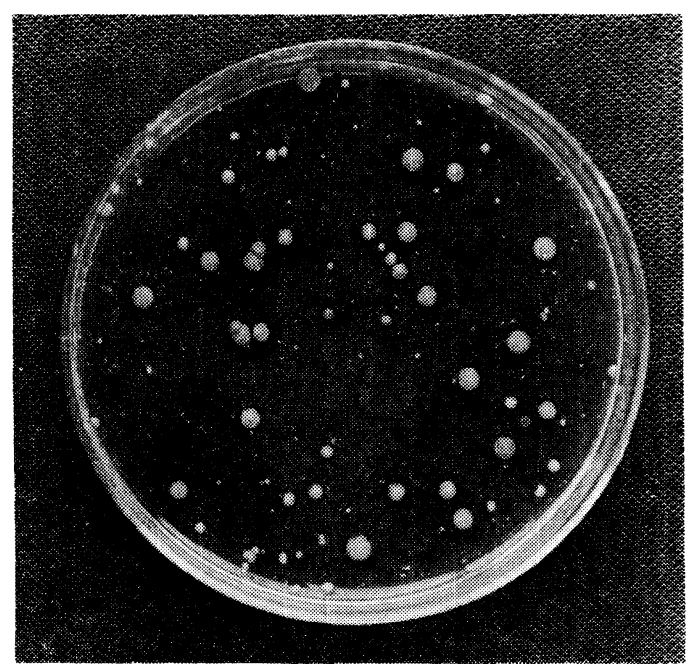

写真 3 細菌のコロニー 
作る。このコロニーは微生物の集合体で，その形状や色 調は微生物の種類で一定した特徵を示すので分類上のて がかりとして重要である。

産業に扔いて利用価值の高い徵生物はカビ, 酵母, 細 菌, 放線菌である。

\section{1 力 ビ}

コウジカビやアオカビのように，清酒，みそ，しょう ゆ，チーズの製造に有益に利用される種類と，植物体に 寄生して農作物の病気の原因になるもの，果物を腐敗さ せるものがある。カビは主として胞子によつて増殖し，
胞子の大きさは $1 \sim 2 \mu$ の球形状を呈する。写真 4 に示 したように，胞子は発芽して Aから Gにみられる順序で 菌系を生長させ，発芽後 1 時間でHの形にまでなる。さ らに多くの枝をのばして 2 時間後には I ， 3 時間後には $\mathrm{J}$ に示した形に生辰し, 胞子が発芽して10時間後にはQ に示したような複雑な形に生長する。このときの菌系体 は $100 \times 100 \mu$ の大きさにひろがり, 肉眼で十分に認め られる。菌系は高等植物の葉やくきに相当する部分であ る。菌系はさらに分化して写真 $\mathbf{5}$ にみられるような子実 体を形成するが，これは花や果実に相当する繁殖器官で

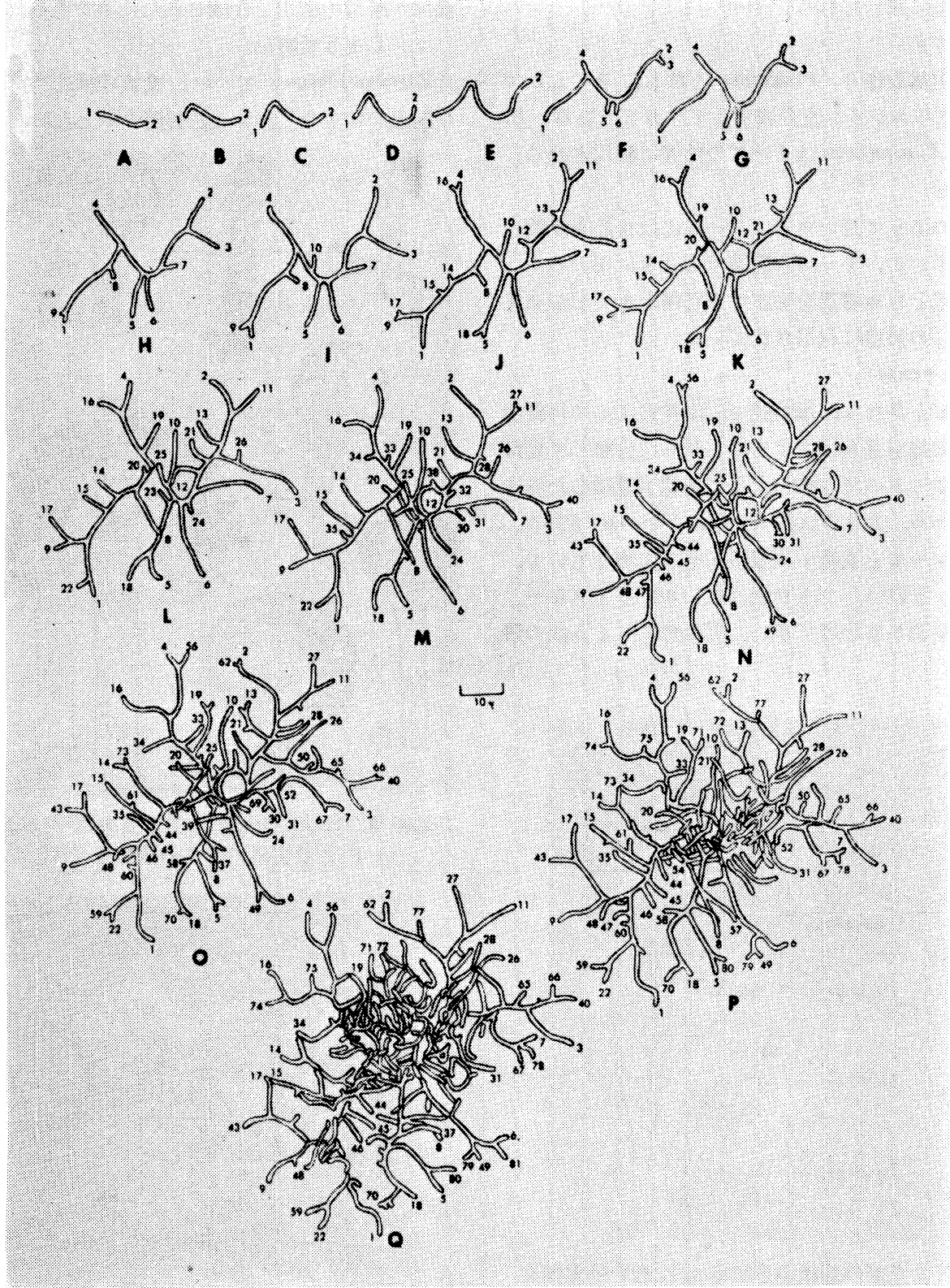

写真 4 力ビの菌系の発育順序 
ある。この子実体はちょうど筆の先端のような形をして いるので Penicillium とよばれ，一般にはアオカビと称す る。写真 6 はコウジカビの子実体である。

(1) コウジカビ

Aspergillus と称し, 酸造や発酵工学に利用される重要 な種類が多い。多種類の酵素を体内で合成し, デンプン タンパク質を分解する性質をもっている。A. oryzae はみ そ，しょうゆ，清酒の製造に重要なカビである。A.gloucus はカッオブシの製造に用いるコウジカビで，カツオ ブシの味と香りを合成する能力をもつている。A. niger は胞子が黒色のカビでクロカビと称し，アワモリショウ チュウの製造に用いられる。

\section{(2) アオカビ}

筆状の子実体を作り，Penicillium と称し，そのなかで P. notatum はペニシリンを合成するアオカビである。 $P$. camemberti と P. roquefortii はチーズの熟成に利用される。

(3) ケカビ

菌禾が毛のように長いカビで，一般には食品を腐敗さ せる種類が多いが，チーズを製造するときに用いるレン ネットの代用となる酵素を生産する有用なケカビが発見 され，チーズの製造に利用されている。

\section{2 酵母 yeast}

酵母はカビと異なり，単細胞で，出芽によって母細胞 から新しい細胞が芽を出すように生長し, 分離して增殖 するが，種類によつては枝のように細胞が連結した形を とるものがある。大きさは約 $8 \sim 11 \mu \times 6 \sim 8 \mu$ である。 酵母はアルコールを生産する種類がその主要なもので, Saccharomyces といい，ブドウ酒，ビール，ウイスキー, 清酒を作る種類がきわめて多い。その他にしょう油の醸

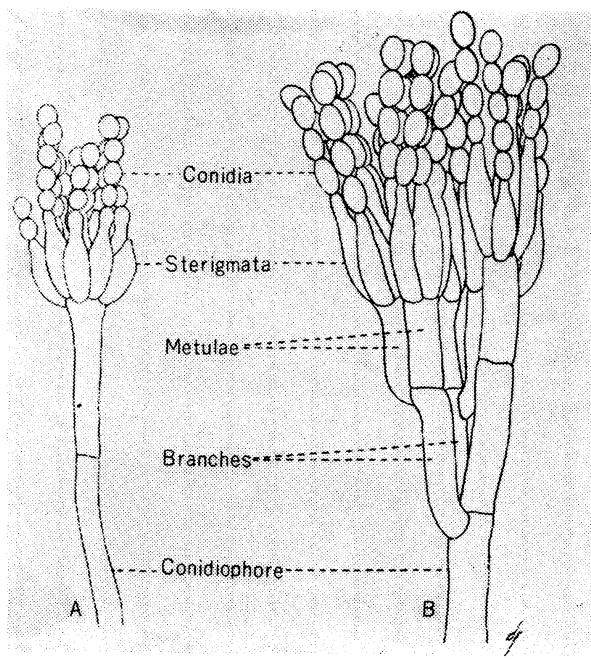

写真 5 アオカビの筆状の子実体 A’は若い子実体を 示す。 $\mathrm{B}$ は十分発育したもの
造のとき活動して香気成分を作るZygosaccharomyces があ る。また細胞内にタンパク質を合成する食用酵母が知ら れている。最近ではプラスチックを分解する酵母や， P $\mathrm{CB}$ を分解する醉母が発見され，公害防止にも人きな意 義をもつ新しい面がひらけてきた ${ }^{20)}$ 。

(1) アルコール酵母:

Saccharomyces cerevisiae と称し $10^{\circ} \mathrm{C}$ 内外の環境で糖液を 発酵してアルコールを作る性質を利用して，ブドウ酒， ビール，ウイスキー，清酒の製造をする。このとき発生 寸る炭酸ガスを利用し，小麦粉と初つて焼くとパンが作 ら机る。パンのよい香りはアルコール，アルデヒド，有 機酸が酵母の作用で合成されたためである。（写真 7 )

(2) しょうゆ酵母

Zygosaccharomyces といい，食塩の濃度の高いしょうゆ やみそのなかでアルコール発酵をいとなみ, 製品に独特

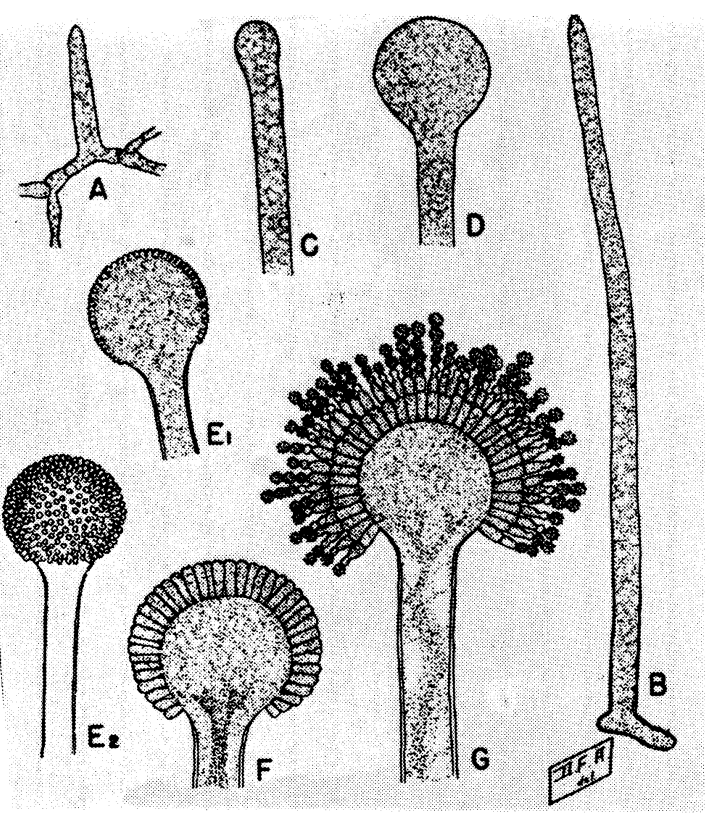

写真 6 コウジカビの子実体菌系 $\mathrm{A}$ から $\mathrm{B}, \mathrm{C}, \mathrm{D}$, $\cdots \cdot \mathrm{F}$ と子実体の生長の順序を示す。

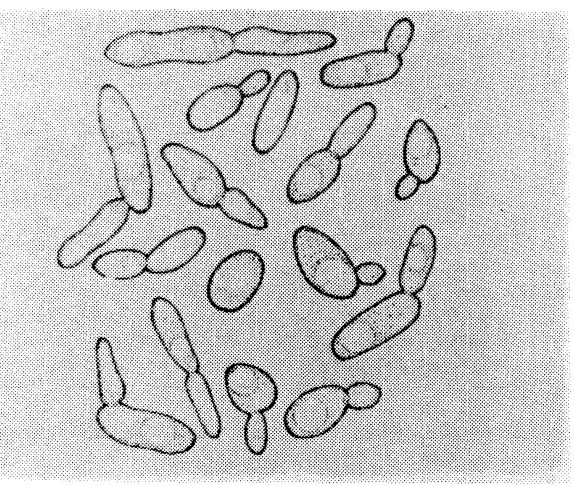

写真 7 アルコール酵母 Saccharomyces cerevisiae 
のよい風味をつける作用をしている。

(3) 食用酵母.

Candida，Torulopsis などと称する種類がタンパク質を 体内に合成寸る能力をもつている（写真 8)。簡単な糖液 と無機の窒素化合物を含む液のなかで増殖し，タンパク 質を細胞内に合成蓄積する。アルコール発酵はしない。 酵母の乾燥粉末の $50 \%$ はタンパク質である。短時間に增 殖し，タンパク質を多量に作り，味のよい個性の酵母を 天然からえらび出してい業的に利用する。糖の代りに石 油の n一パラフィン，天然ガスを資化する酵母が実用上 の価值が高い。

\section{3 細菌 bacteria}

$0.5 \sim 2.0 \mu \times 1 \sim 5 \mu$ の大きさの単細胞で，球状，桿状， ラセン状の 3 種に分類される。もっとも小さい細菌は $0.5 \mu$ といわれる。分裂によつて增殖する。写真 9 のよ うにベン毛をもつ種類やブドウ状に集合しているものな ど種類が多い。土壌菌, 病源菌, 発酵菌, 腐敗菌がその 代表的なものである。

(1) 乳酸菌

乳糖を発酵して乳酸を作り，Lactobacillus bulgaricus は よい味と香りを作るので，チーズやヨーグルト製造の主 要菌として用いられる。

(2) バチルス Bacillus

枯草，土壌に多く分布し，胞子を形成し，胞子は 100 ${ }^{\circ} \mathrm{C}$ 以上の熱にも耐えるので殺菌を十分にしないと完全に 菌の作用を止めることができない。Bacillus は腐敗菌の 代表で，強力な酵素を合成し，物質を分解する力がつよ く食品，工業材料の変資の原因となる。Bacillus のなか でB. natto はナットウの製造に用いる菌である。最近は 細菌の酵素の利用法がひらけ，匹場で菌を大量に増殖 させ, 酵素を精製し, 商品化する傾向がみられ，その利 用の可能性は広く，将来性がある。

(3) シュードモナス Pseudomonas

ベン毛をもち，緑，青・紫のケイ光を発する菌であ る。代表的な緑膿菌 (Pseudomonas aeruginosa) は自然界に 広く分布し，土壌，河川，池，下水，海水か门容易に分 離される。病源性のある種類が多く，アメリカでは化粧 品のなかに增殖し，知らずに用いて死しした例ゔある。

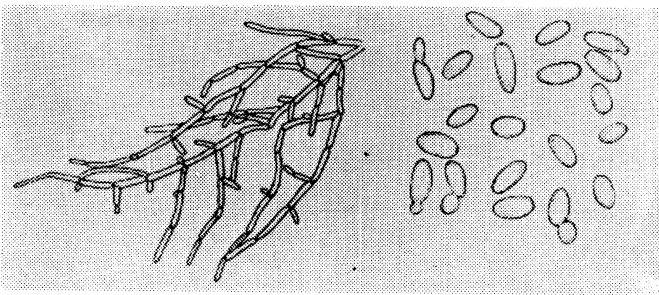

写真 8 食用酵母 Condida utilis
一般には腐敗菌とされ，魚には多く付着している。

しかしPseudomonas菌は生活力がつよく，また変つた能 力や個性をもつ種類が自然界から多く分離され，その新 しい利用価值が重視されるようになった。メタンを炭素 源として資化するPs. methanica ${ }^{21)}$, Ps. methanitrificans ${ }^{22)}$, メタノールを栄養源として利用する能力のあるPs.aeruginosa, Ps. dacunhae, Ps. denitrificans, ガス状の炭化水素 望資化する Ps. propanica ${ }^{23)}$, Ps. radiobacter ${ }^{24)}$, Ps. liquefaciens ${ }^{25)}$ などが分離されている。

また工場廃水のなかの色素や染料を分解して脱色する 力のあるPseudomonas が分離された。河川のなかに残留 寸る有機水銀化合物を分解して無機の水銀に変化させる 作用をもつPseudomonas ${ }^{7}$ など，公害を積極的に防止す る可能性が微生物の能力で将来は広く実現する時代にな りそうである。

\section{4 放線菌}

大きさは細菌に近く, 形状はカビと似ている中間体と 考えられる微生物で，土壌から多く分離される。1943年 にアメリカで Waksman 污放線菌からストレプトマイシ ンを合成する種類を発見してから放線菌がみなおされ， その後多くの抗生物質が生産されるきっかけとなつた。 主な抗生物質とそれを生用する放線菌を示す。

$$
\begin{aligned}
& \text { ストレプトマイシン } \\
& \text { クロラムフェニコール } \\
& \text { オーレオマイシン } \\
& \text { テラマイシン } \\
& \text { エリスロマイシン } \\
& \text { カナマイシン }
\end{aligned}
$$

Streptomyces griseus

Streptomyces venezuelae

Streptomyces aureofaciens

Streptomyces rimosus

Streptomyces erythrens

Streptomyces Kanamyceticus

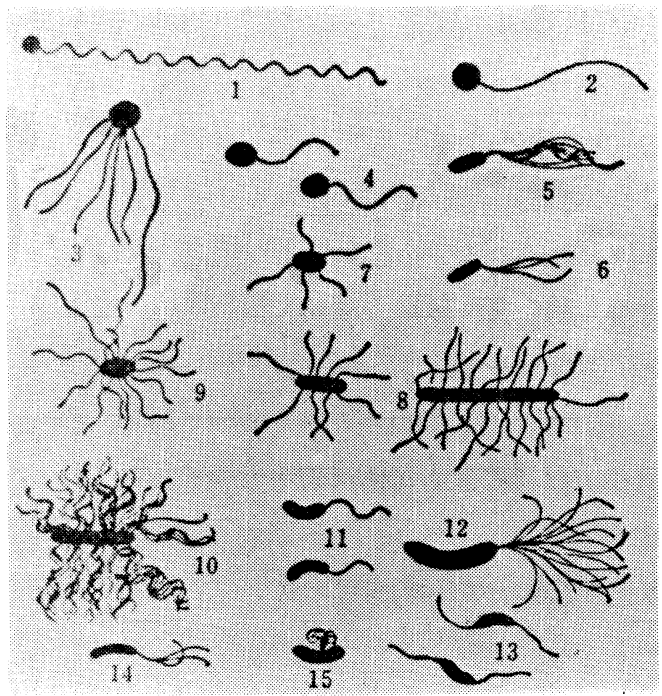

写真 9 ベン毛をもつ細菌の種類たとえば，4. 硝酸 菌，7. 大腸菌，8.B. subtilis，9. チフス菌，11. コ レラ菌など 


\section{5. 微生物の産業における新しい利用法}

\section{1 抗生物質}

アオカビの 1 種, P. notatum がペニシリンを作ること は偶然にわかつたこよで, Fleming が研究空でブドウ球 菌の実験中に空気中から野生のアオカビがシャーレのな かに污染して繁殖したため，その失敗が幸運にも新しい 抗生物質の発見をもたらした結果になつた。これがきつ かけになつてアメリカで Waksman がストレプトマイシ ンを生産する放線菌を発見する大きな成果を生んだ。こ れは結核の治療薬としてペニシリンとともに抗生物質の 真価を世に認識させた。それ以来クロラムフェニコー ル，クロルテトラサイクリン，エリスロマイシンなどの 有用な新しい抗生物質がつぎつぎと放線菌の分離から生 産できるようになり，実用化されたものは50種におよん でいる。抗生物質はつぎに示すような複雑な構造をも つ。

(1) ペニシリン<smiles>[R]NC1C(=O)NC1SC(C)(C)C(=O)O</smiles>

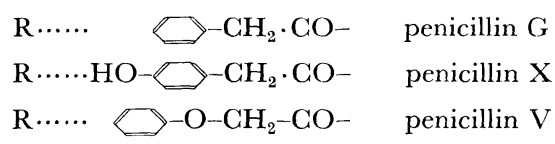

(2) ストレプトマイシン
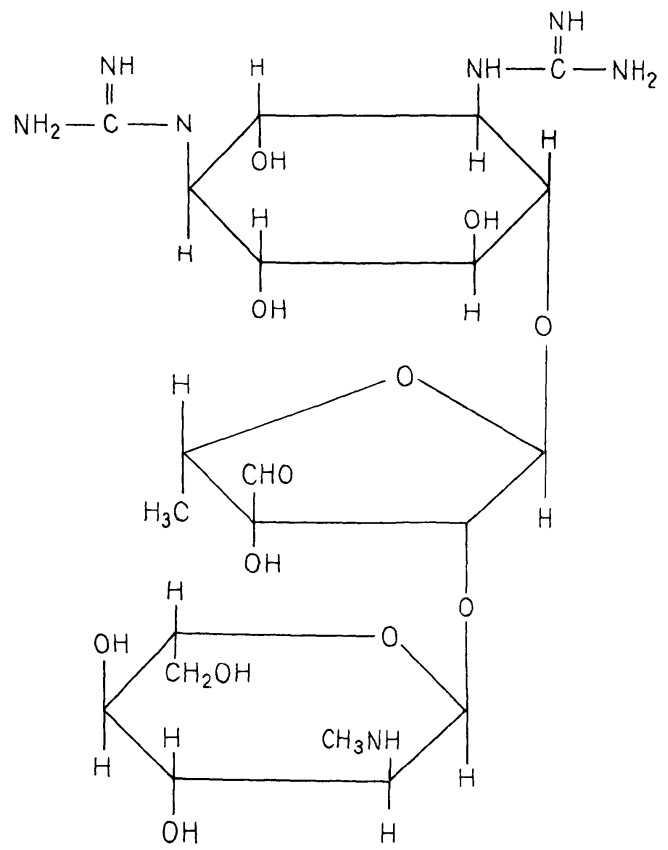

(3) クロラムフェニコール<smiles>O=C(NC(CO)C(O)c1ccc([N+](=O)[O-])cc1)C(Cl)Cl</smiles>

(4) テトラサイクリン<smiles>CCCCN(C)[C@H]1C(O)=C(C(N)=O)C(=O)C2(O)C3C(=O)c4c(O)cccc4C(C)(O)C3C[C@H]12</smiles>

これらの構造のらち, クロラムフェニコールだけは現 在の合成化学:の力で合成することに成功し, 大量に作ら れているが，その構造も微生物に教わつた結果による。 クロラムフェニコールは従来は放線菌によつて合成され る抗生物質とされていたが，最近の新しい技術によると パラフィンの混合物 $\left(\mathrm{C}_{12}, \mathrm{C}_{13}, \mathrm{G}_{14}\right.$ のフラクション) と 無機窒素化合物を含む培地のなかで発育する細菌によつ ても生麾されることが明らかになつた ${ }^{26)}$ 。新潟県の油田 地帯で分離された Corynebacterium sp. KY4339 という細 菌は, $\mathrm{n}$-パラフィンを炭素源に利用して培地の水層部に $p$-nitrophenylserinol を $3 \mathrm{mg} / \mathrm{ml}$ の割合で生産する。こ れを化学的に加工することによつてクロラムフェニコー ルに寸ることができる。細菌にたいしては低濃度 $(2 \sim 20$ $\mu \mathrm{g} / \mathrm{m} l)$ で有効で, 肺炎菌, チフス菌, 変形菌, 大腸菌, 枯草菌に広く医薬品として効力を発揮する。生産能率が よく，従来の方法よりもコストダトンできる見通しだと いわれる。

\section{2 バクテリア・リーチング}

バクテリア・リーチングという言葉が10年ぐらい前か ら欧米で使われはじめた。その意味は細菌類による金属 鉣物および鉣石からの有用金属の溶出のことである。鉱 業と微生物との境界領域の技術として，また新しい分野 の開拓ということで, 釯莱関係者, 微生物の研究者から 注目されるようになつた。

最近油田, ガス田, 鉱山, 海洋, 湖沼などの微生物に 関する研究がしだいに進歩して, 石油, 天然ガスなどの 然料鈗物の鉣床, 硫化鉱鉱床, 鉄鉱鉱床の形成き変化に ついての微生物の役割が明らかにされた。きた微生物の 機能や作用を応用して油田, 天然ガス田, 金属鉱床を微 生物によつて探査し, 回収の研究が発達しつつある。と くに品位の低い鉱石から微生物の作用を応用して金属を 回収することがにわかに活発になつてきた。

これらの微生物は鉱山，炭鉣などの抗内水のなかに多 く分布していること於明らかになつた。主としてイオウ 
およびイオウ化合物を酸化してエネルギをうるイオウバ クテリアThiobacillus と, 鉄を酸化するFerrobacillus がバ クテリア・リーチングに利用される。その主なものを示 す。

Thiobacillus thiooxidans

Thiobacillus concretivorus

Thiobacillus ferrooxidans

Ferrobacillus ferrooxidans

Ferrobacillus sulfooxidans

バクテリア・リーチングの理論については，有用金属 の溶出は純化学的反応であつて, 細菌はこの溶出に必要 な溶液条件をととのえるときに, 細菌が触媒的な作用を して有効に働いているという考えと，細菌自身が，鉱物 や鈗石中の有用金属に直接に作用して溶出しているとい う説とがある。すなわち T. thiooxidans などのイオウ酸 化細菌は，イオウを酸化して $\mathrm{H}_{2} \mathrm{SO}_{4}$ を作り，F.ferooxidans などは，硫酸第 1 鉄を酸化して硫酸第 2 鉄を生成す る能力をもつているという。これらの生産物は鉱石の化 学的浸出液で有効な溶剤として役立つていると考えられ ている。また細菌の直接の作用によつて, 鉄バクテリ アは，第 1 鉄塩を第 2 鉄塩に酸化するばかりでなく， $\mathrm{CuS}$ や $\mathrm{S}$ を溶解し, 黄銅鉱やニッケル鉣その他の金属 硫化物を直接とかし出すといら説もかなり認められてい $る^{27)}$ 。

カナダの Elliot Lake 地区の抗内水にはバクテリアが 存在し，これが酸化鉄を含む酸性酸化溶液を作り，ウラ ニウムの抽出に役立つことがわかり，このバクテリアは Ferrobacillus-Thiobacillus に属することが明らかにされ た。この細菌によるウラン抽出の性能を調査するために 鉣石の粒度，抽出液の $\mathrm{Fe}$ の濃度，酸性度，培地の栄養 素などウラン抽出速度におよぼす影響がくわしく研究 された ${ }^{28)}$

新しいウラン鉣を粉砕し, 径 2 インチの管に $400 \mathrm{~g}$ ず つつめ, $600 \mathrm{~m} !$ の抽出液を $10 \mathrm{ml} / \mathrm{min}$ の流速で流下さ せ，この液はふたたび循環させて使用した。抽出液の最 初の $\mathrm{pH}$ は硫酸で 2.0 にし，これに硫酸第 1 鉄と硫安 $(3 \mathrm{~g} / l)$ ，オルソリン酸カリウム $0.5 \mathrm{~g} / l$ を加え，これに細 菌を加え繁殖させて用いた。試料のウラン鉱の $\mathrm{U}_{3} \mathrm{O}_{8}$ の 含有量は0.11〜0.15\%で，鉱石の粒は $8 \sim 14$ メッシュの 場合は 12 週間で $90 \% ， 14 \sim 20$ メッシュの試料では 6 週間 で $90 \%$ のウラン抽出率となつた。バクテリアを含まない 液の場合にはウランが $9 \%$ しか抽出されなかつた。 $\mathrm{U}_{3} \mathrm{O}_{8}$ が $1 \mathrm{~g} / l$ の溶液中でもバクテリアはよく繁殖した。廃鉱 でも実験は成功し，抽出法としてはすぐれた成績を示す ことが実証されている。

さらに Harrison らの実験では Elliot Lake Ontario の ウラン鉣は $3 \sim 6 \%$ $\mathrm{FeS}_{2}$ を含み, 同じ種類の Ferro-
bacillus-Thiobacillus 系の細菌の酸化作用で硫酸が生成さ れその結果として4 価のウラニウムを可溶性の 6 価のウ ラニウムに変えることができると報告している29。

Zajic らの実験では $\mathrm{U}_{3} \mathrm{O}_{8}$ を $0.356 \%$ 含む鉣石を粉砾 し，フラスコの培地に加えてオートクレーブで殺菌し， 前報と同じ系統の細菌を接種して $28^{\circ} \mathrm{C}$ で 200 r.p.m の振

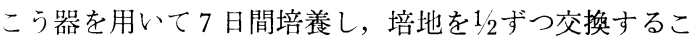
とにより，最終的には $98.5 \%$ のラニウムを回収するこ とに成功している ${ }^{30)}$ 。

銅を鈗石からバクテリア・リーチングによつて回収す る技術もかなり実用上の利益をえている。18世紀の技術 では鈗石中の銅が $10 \%$ 以上含まれていないと経済的にひ き合わなかつた。その後鉣石からの分離法の改良によつ て1920年代には $2 \%$ の銅含有量でも抽出することが可能 になつた。微生物を用いると銅が $0.25 \%$ の低含有量の鉱 石からも完全に回収できる点が特徵である ${ }^{31)}$ 。この銅の 回収にもウラニウムの場合と同じ系統のバクテリアが用 いられる。銅を溶出するくわしいメカニズムは直接的な 酸化と間接的なプロセスにわけてつぎの式で説明され る。

$$
\begin{aligned}
\mathrm{CuFeS}_{2}+4 \mathrm{O}_{2} & \longrightarrow \mathrm{CuSO}_{4}+\mathrm{FeSO}_{4} \\
\mathrm{CuFeS}_{2}+2 \mathrm{Fe}_{2}\left(\mathrm{SO}_{4}\right)_{3}+2 \mathrm{H}_{2} \mathrm{O}+3 \mathrm{O}_{2} & \\
& \longrightarrow \mathrm{CuSO}_{4}+5 \mathrm{FeSO}_{4}+2 \mathrm{H}_{2} \mathrm{SO}_{4}
\end{aligned}
$$

バクテリア・リーチングによつて鈗山の廃液からも金 属が回収できるので，河川への公害を防止することにも 役立つといわれる。

\section{3 微生物のプラスチック分解への応用}

プラスチック材料は現在ではその種類が70種にもおよ び，広く実用化されているものは約20種といわれ，さら に新しい材料が作りだされている。一般にプラスチック 材料は物理的にも化学谈にも安定な特性をもつていて， 微生物の作用を受けることがなく，したがつて微生物に よつて変質腐食されるようなことはないと信じられてき たが，筆者の広範囲の工業材料，製品などの微生物災害 の研究から，プラスチックの種類によつてはカビやバク テリアの作用を受けやすい事例がしだいに明らかになつ てきた。

イギリス化学会でも各種のプラスチック材料の試料を 4 年にわたつて各地の土脿中に埋めておいて，取りだし た試料について物性を柧べたがまつたく変化が起こらな かつたことから，プラスチックは微生物の作用を受けな いとの結論に達している32)。わが国でも同じように各地 の土中にプラスチック片を 2 年間埋没させる試験を行な い，土壌微生物の作用で分解させようと試みたが，みる ベき成果がえられていない。MIL 規格のなかには航空 機の部品や材料の試験として土中埋没試験法 が制定さ $れ^{33)}$ ，これはある程度参考になるが，プラスチック材料 


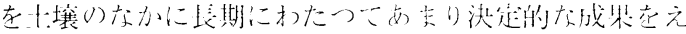
ていない。

また MII、の規格ではポリアミド，ボりカーボネート， ポリエチレン、ポリプロヒレン，ポリスチレン，シリコ

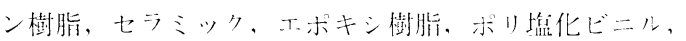

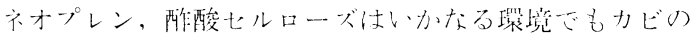

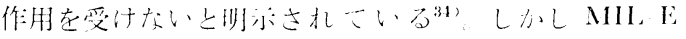

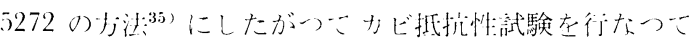

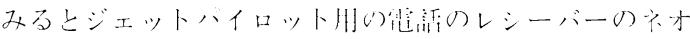
プレンレトイロンの)舩少にクロカビ(Aspergillus niger) 上 コウジカビ (Aspergi!lus fauus) が繁殖して腐食が発生した 例がある36)。アメリカでの試験結果ではカビにたいして 安定であると判定された材料でも，父候風士:の未つたく 異なる地区では反対の結果がでるのが微生物の作用の特 徴のように感じら狄る。その点を今後は重視しなけ机代 ならない。

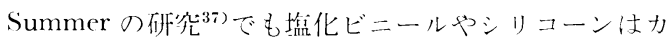
ビにたいして抵抗性:の十分に亦る上遮べに㧈ているが，

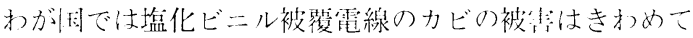

はげしいことが明にかになつてきた。写真10〜12はポリ

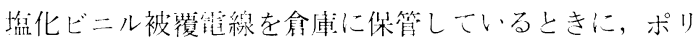
睢化ビニルの部分に発生したカビである。製品を倉庫に 收納する上男いものは1打でポリ塩化ビニルの表西に カビが㥕令し，カビをふき取一てもシミが残り，小さな

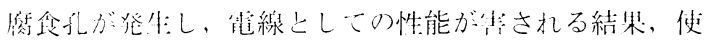
田不能になるここような例は電気絶䋑材料，ハッキン グ，建材，1:木脚水材料などの日的に使用される数種 のク゚ンスチックにも発思さ机ている。これらの事例はい 末末でり微生物によるプラスチックの変質や分解, 垃

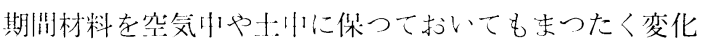
が打こけないといら定説 ${ }^{32}$ に反する璄象ともいえるもの で女る。こ机らのいくつかの例を総合的に集約し，研 究の成果が獘理できるようなデータがえられれば，微生 物によるプラスチックの分解処理法が明らかになるとと もに，公掑題上して深刻な兴みとなつているプラスチ ックの発㖼処理にも态用が可能となる日がくるものと考

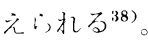

最終的には微牛物に分解されやすい材料，きおめて安
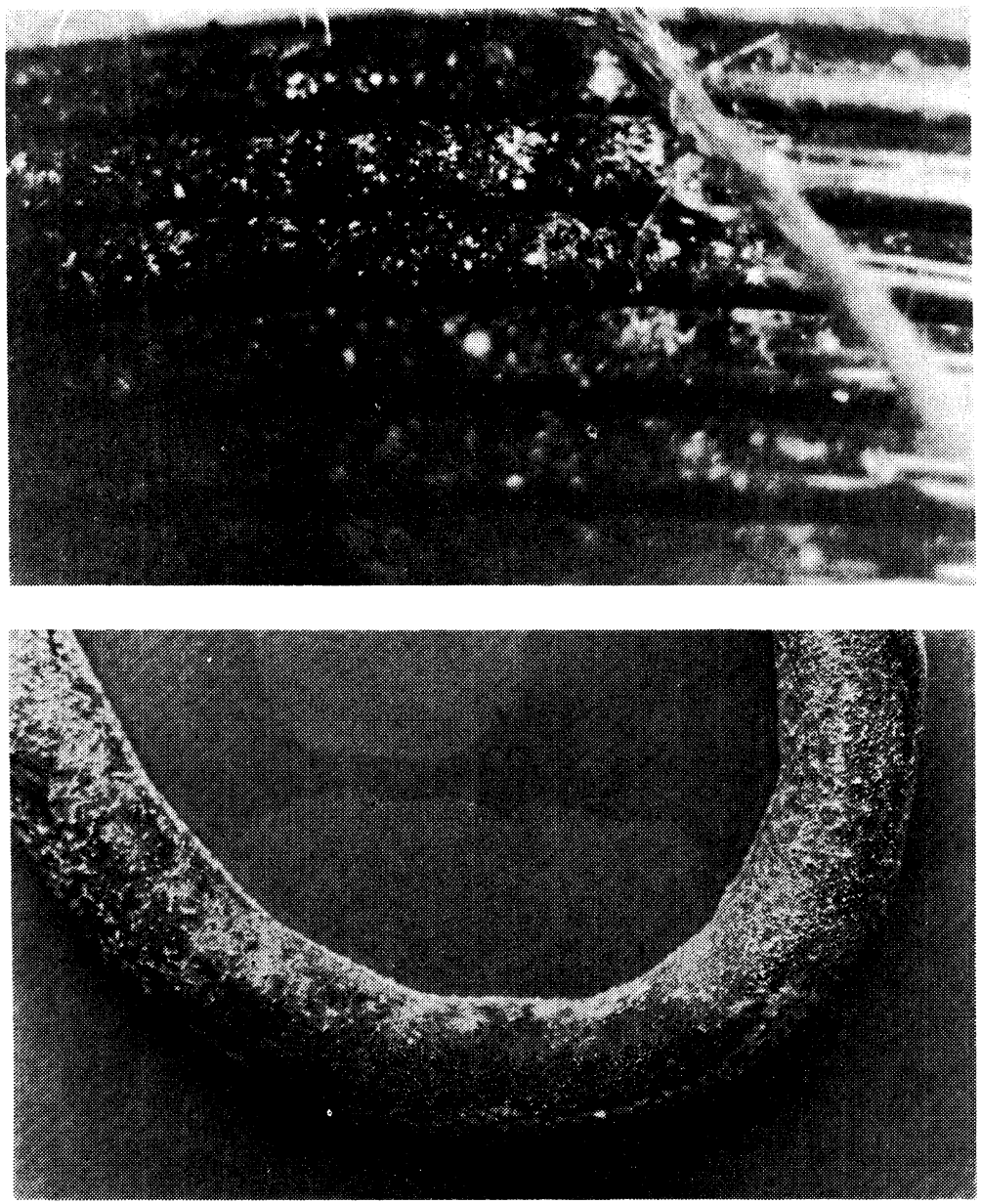

写真10 ポリ塩化ビニル被覆電 線は令庫の中に保存するとカ ビが発青しやすい。
写真11 電線の被覆 (PVC) に 発育したカビ 
定な材料などの区分を明確にできれば，汎用のプラスチ ックには使用後微生物処理の可能な材料を用いる方針が 確立される。また微生物による分解のメカニズムが解明 ができれば，それを応用して微生物処理の可能なプラス チックを考案することもできる。

現在までの研究結果でもつとも微生物の作用を受けや すい材料はポリウレタン樹脂 ${ }^{39)}$, 酵母によるポリ塩化ビ ニル樹脂の分解が明らかにされている ${ }^{40)}$ 。また，ポリス チレンもカビによつてある程度の影響を受けるといわ れ ${ }^{41)}$ ，比較的安定性の高いエポキシ樹脂もカビの作用を 受ける ${ }^{42)}$ 。ポリスチレンは光の作用で分解しやすい事実 が知られ ${ }^{43)}$ またポリエチレンなどを薬品で分子結合を 切り ${ }^{44)}$, 光でさらに崩壊される技術が考案されている。 今後はやはり時間をかけて総合的に研究し, 物理的, 化 学外な方法に微生物学的な技術を結びつけて目的を達す るようにすべきと考えている。微生物によるプラスチッ クの分解の試験法やその評価についても案が示されてい るにすぎない45)。これらの考えを基礎にしてさらに研究 を進めたい考えである。

\section{4 公害防止への応用}

公害にたいする認識がこの 1 年ぐらいの間に社会的に も日常の生活にも急速に高まつている。国際的な会議が ひらかれ ${ }^{47)}$ ，〈わしい調査や安全基準量の作成などが急 がれている。しかし現在の状況から判断すると地球上の 自然環境の污染は調査が進むにつれ，まことに憂慮すべ

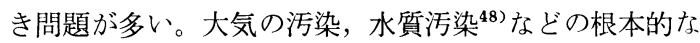
事項のうち, 積極的にそれを浄化することが望ましく49), これ以上環境污染を増加させないための具体的な対策を 急ぐとともに，その1つの方法として微生物の力を今後 は水質污染の浄化の方面に有効に応用することが有望視
される方向がひらけてきたので，さらにそのような研究 テーマを強力に推進したいものである50)。

Hsich の研究によると, 齒薬のパラチオンを含む廃液 処理を, パラチオンを炭素源に利用する能力をもつ細菌 Pseudomonas sp. を培養堌殖させることにより無毒化する ことに成功し， $1,000 \sim 5,000 \mathrm{ppm}$ のパラチオンを含む 廃液が完全に炭酸ガスに分解したといわれる ${ }^{6)}$ 。また水 銀に抵抗性をもつPseudomonas 菌が土壌から分離され， この細菌の増殖させて細胞液から酵素を分離し，その酵 素作用によつて有機水銀化合物のうち，フエニル酢酸水 銀を無㙨の水銀とベンゼンに，エチルリン酸水銀を水銀 とエタンに, メチル塩化水銀を水銀とメタンに, 塩化水 銀を水銀にそれぞれ還元分解することに成功し，この研 究は微生物の能力による水中, 土中の残留有害物質の分 解と無毒化に大きな真価と将来性を示したものとして注 目に価寸る门。

$$
\begin{aligned}
& \mathrm{C}_{6} \mathrm{H}_{5}-\mathrm{Hg}^{+} \longrightarrow \mathrm{Hg}^{\circ}+\mathrm{C}_{6} \mathrm{H}_{6} \\
& \mathrm{C}_{2} \mathrm{H}_{5}-\mathrm{Hg}^{+} \longrightarrow \mathrm{Hg}^{\circ}+\mathrm{C}_{2} \mathrm{H}_{6} \\
& \mathrm{CH}_{3}-\mathrm{Hg}^{+} \longrightarrow \mathrm{Hg}^{\circ}+\mathrm{CH}_{4} \\
& \mathrm{Hg}^{++} \longrightarrow \mathrm{Hg}^{\cdot}
\end{aligned}
$$

よごれた川の水を，薬品のに抢いを残さないで浄化す る技術が新しく考案された ${ }^{51)}$ 。従来の浄化法のように薬 品処理するのではなく, 川底の石などには付着している 水アカ状の微生物が水を浄化することに着眼した方法で ある。川の水汸長い距離を流れるらちに，川底の微生物 の作用を受けて水中の污物が少しずつ処理されて水が浄 化される。そこで径 $1 \mathrm{~cm}$, 長さ $1 \mathrm{~m}$ の 6 角形の管をは ちの巣状にならべこの管の内部に微生物の膜を形成さ せてから，水をくりかえし循環させる方法を実験した結 果，川の水が長い距離を流れたのと同じ効果がでて，き

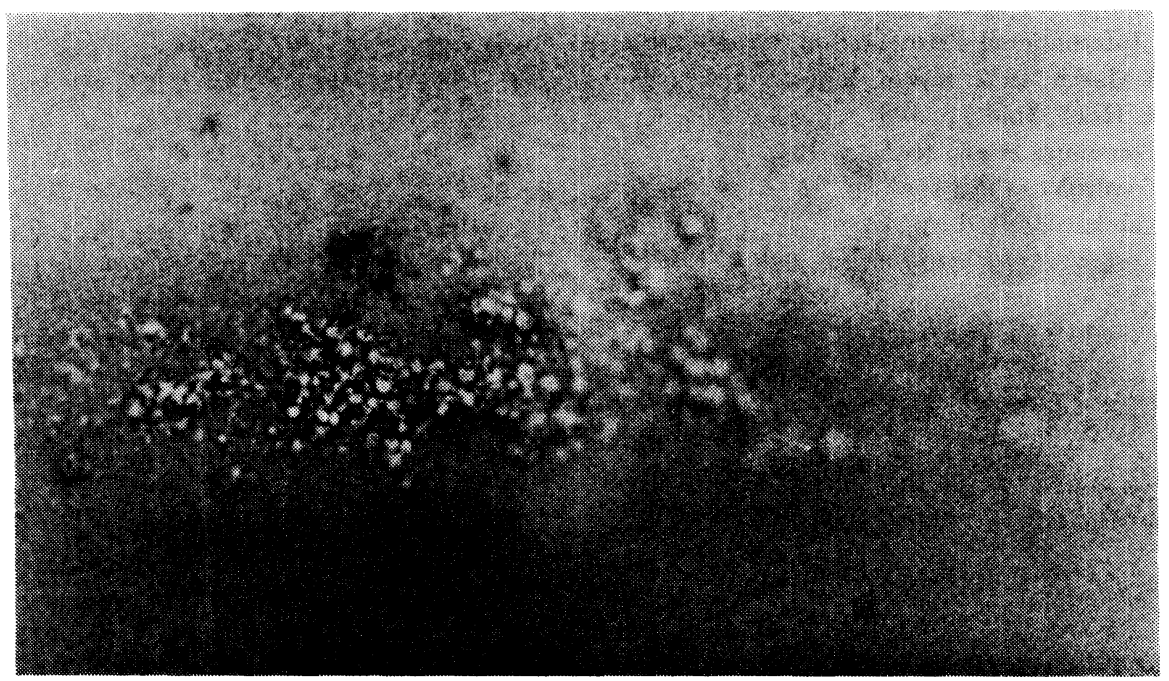

写真12 ポリ塩化ビニルの表面に発生したカビのコロニー。プラスチックが腐食される。 
わめてよい成果がえられている52)。この方法によると水 中のアンモニア，シアン，合成洗剂などが分解されるの で，この方法が実用化すると下水処理と結合させて，将 来下水処理水をふたたび飲料水に活用寸ることも可能と なりそうである。

また川のなかに流计した有機水銀剤は，そのほとんど が20〜30時間で水中の藻類に吸収されることが最近の実 験からわかつた。その結果, 藻類の体内の有機水銀濃度 が河川の濃度の 17,000 倍に上昇した。同じようなことが 水中の虫の体内でもおこり, 藻類や虫を食べた魚の体内 でも河水の水銀が11,000倍以上の濃縮される事実が実験 の結果から明らかになつた ${ }^{53)}$ 。水俣湾や阿賀野川で，大 量の水銀が魚の体内に蓄積されるにいたつた食物連鎖の メカニズムがこの研究の結果から解明できるばかりでな く,この藻類の機能を合理的に利用して河水のなかにと けている有機水銀化合物を完全に吸収させ, 浄化された 水のなかで魚を飼い，ノリの養殖をす机ば安心して魚や ノリを食べることができる。このような微生物のも本質 的な機能については，今までほとんど研究されていない ので，今後の実験汸幅広く進めば公害防止のうえでもつ ともすぐれた新しい技術となろう。微生物研究の大いに 期待される方向がひらかれようとしている。

\section{参 考 文 献}

1) 井上: 応用微生物の方向, 橹書店, (1970), p. $1 \sim 47$; 続応用微生物の方向, 槙書店, (1972), p. $1 \sim 19$.

2) 微生物ハンドブック編集委員会: 微生物ハン ドブック，技報堂，(1967) p. 922 923.

3) T. A. Layton: Cheese and Cheese Cookery, The Wine and Food Society Michael Joseph, (1967).

4) 加藤 : 化学と工業 21, (1968), p. 451.

5) 4th. International Fermentation Symposium, 20 25 March, 1972, Kyoto, Japan.

6) P. H. Hsieh, Ibid.; p. 103

7) K. Tonomura et al.; Ibid., p. 104

8) N. Tomizuka et al.: Ibid., p. 92.

9) E. Katchalski: Ibid., p. 64

10）井上：続応用微生物の方向, 橹書店, (1972), p. 3.

11）木下: 発酵工業, 大日本図書, (1970), p. 114 $\sim 132$.

12）原田篤也：化学と工業，23, (1969), p. 1241 1243.

13）食品衛生調査会毒性部会，(1970年 9 月26日).

14）田中二良：技術ジャーナル No. 500 (1969. 5. 16).

15）技術ジャーナル No. $556(1970,6,12)$

16) 日本工業新聞 No. 7953 (1970. 10. 24)

17）技術ジャーナル No. 598 (1971.4.2)

18) J. H. Litchfield: Develop. Ind. Microbilogy,
11, (1970), p. $341 \sim 349$

19) 井上：応用微生物概論, 日刊工業新聞社, (1969), p. 2.

20) 朝日新聞 (1972.4.6)

21) M. Dworkin and J. W. Foster: J. Bact., 72, (1956), p. 646

22) J. B. Davis et al.: J. Bact., 88, (1964), p. 468

23) M. Dostale R: Cesk. Biol., 30, (1954) p. 173

24) V. M. Bogdanova: Mikrobiologiya, 35, (1966), p. 787 .

25) Z. P. Telegina: Ibid., 35, (1966), p. 1059.

26) T. Suzuki et al.: 4th International Fermentation Symposium, (1972), p. 200.

27) 岩本: 金属, (1967.9.15) p. 40

28) V. F. Harrison: J. Metals, 18, (1966), p. 1189

29) V. F. Harrison et al: Can. Mining J. 87, (1966) p. $64 \sim 67$

30) J. E. Zajic et al: Develop. Ind. Microbiology, 11, (1970), p. $413 \sim 419$.

31) A. W. Fletcher: Microbial Aspects of Metallurgy (ed. by J. D. A. Miller), Medical and Technical Pub. Co. (1971) p. 183.

32) 技涂ジャーナル No. 569. (1970.9.11)

33) MIL-F-8261 A (USAF) 20. Dec. (1955).

34) MIL-STD-454B: Fungns Inert Materials.

35) Military Specification Fungns Resistance Test. (MILE-5272C).

36）井上：続応用微生物の方向, 槇書店, (1972), p. 150.

37) W. Summer: Corrosion Technology, (1964 April) p. $19 \sim 21$.

38) 井上: PPM, 2-6, (1971), p. 68.

39) A. M. Kaplan et al.: Develop. Ind. Microbiology, 9, (1968), p. $201 \sim 217$.

40) J. L. Osmon et al.: Ibid., 11, (1970), p. 447 452.

41) 神野：日本菌学会 (1972), 講演要旨 p. 41 .

42) 井上：電子科学, 22-2, (1972), p. $71 \sim 77$.

43) 蓮沼: PPM, 2-6, (1971), p. 40 45.

44) 朝日新聞, 1972. 5. 20.

45) ASTM D1924-63. および ISO/TG61/WG6 (TGA) 197.

46) 井上: 化学工業, 23-8, (1972) p. 53 62.

47) 国連人閒環境会議, ストックホルム (June, 1972).

48) A. H. Walters: Biodeterioration of Materials Vol. 2. Applied Science Pub. (1972).

49) H. W. Englund: Procedings of 2nd. International Clean Air Congress, Academic Press. (1972).

50) R. Mitchell: Water Pollution Microbiology, Wiley, (1972) p. 383.

51) 日本経済新聞 (1972.5.1).

52) 朝日新聞 (1972. 5.29).

53) 朝日新聞 (1972.4.5). 